STUDI

FRANCESI

\section{Studi Francesi}

Rivista quadrimestrale fondata da Franco Simone

185 (LXII | II) | 2018

OCTAVE MIRBEAU: UNE CONSCIENCE AU TOURNANT

DU SIEECLE - sous la direction de Ida Merello

\title{
MONIQUE PEYRAFORT-HUIN, Jeanne de Bourbon et ses livres
}

\section{Maria Colombo Timelli}

\section{(2) OpenEdition \\ Journals}

Édition électronique

URL : http://journals.openedition.org/studifrancesi/13137

DOI : $10.4000 /$ studifrancesi. 13137

ISSN : 2421-5856

Éditeur

Rosenberg \& Sellier

Édition imprimée

Date de publication : 1 août 2018

Pagination : 296

ISSN : 0039-2944

\section{Référence électronique}

Maria Colombo Timelli, « monique PEYRAFort-huin, Jeanne de Bourbon et ses livres», Studi Francesi [En ligne], 185 (LXII | II) | 2018, mis en ligne le 01 septembre 2018, consulté le 06 janvier 2021. URL : http:// journals.openedition.org/studifrancesi/13137; DOI : https://doi.org/10.4000/studifrancesi.13137

Ce document a été généré automatiquement le 6 janvier 2021.

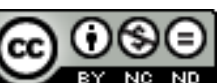

Studi Francesi è distribuita con Licenza Creative Commons Attribuzione - Non commerciale - Non opere derivate 4.0 Internazionale. 


\title{
MONIQUE PEYRAFORT-HUIN, Jeanne de Bourbon et ses livres
}

\author{
Maria Colombo Timelli
}

\section{RÉFÉRENCE}

MONIQUE PEYRAFORT-HUIN, Jeanne de Bourbon et ses livres, «Bulletin du bibliophile», 2017, 1, pp. 43-66.

1 Même en l'absence d'un inventaire de ses biens personnels - document qui a cependant dû être établi à sa mort en 1378 - M.P.-H. essaie de reconstituer la collection des livres de Jeanne de Bourbon, épouse discrète de Charles $\mathrm{V}$, en se basant sur les inventaires royaux; outre un Bréviaire, Jeanne posséda certainement un manuscrit de Sidrac, un $\mathrm{Ci}$ nous dit, une Somme le roi, un Gouvernement des princes, mais aussi des œuvres littéraires: une copie des Enfances Ogier d'Adenet le Roi, Robert le Diable, Florimont et même des romans de matière arthurienne. Quelque vingt-cinq manuscrits au total, portant parfois les armes de la reine, n'en font pas «une bibliophile de premier rang» (p. 63), mais témoignent d'un intérêt certain pour les livres. En annexe, on trouvera la «liste des manuscrits associés à Jeanne de Bourbon» (pp. 64-65). 